\title{
The Influence and Development One of the "One Belt, One Road" Cross Border Ethnic Groups on the Economic and Trade Cooperation Between the Central Asian Countries
}

\author{
Ruimin Zhang* \\ Shaanxi Normal University "One Belt One Road" and Central Asia Research Collaborative Innovation Center, Xi'an, \\ Shaanxi,China \\ *Email: grisha168@gmail.com
}

\begin{abstract}
"One belt, one road" is the key to trade and energy development in northwest Asia and Central Asia. "One belt, one road", is put forward to promote the development of the world economy. The influence and development research methods of the northwest border cross border ethnic groups on the economies of Central Asian countries are analyzed. The main differences in trade, infrastructure, opening up and political environment of Central Asian countries are analyzed. On this basis, one side proposed the "one belt, one road" initiative. To study the development of trade in transnational countries and provide reference for bilateral economic and trade cooperation and bilateral economic development.
\end{abstract}

Keywords: one belt, one road, ethnic groups, Central Asian economic and trade, economic development

\section{INTRODUCTION}

"One belt, one road" is an important strategy for transportation infrastructure construction and interconnection and transportation facilitation, and is conducive to the development of central and Northwest China $^{[1]}$. In the Central Asian countries, Northwest China is characterized by dry climate, small population, numerous nationalities and ethnic integration. In particular, Northwest China, such as Xinjiang, is closely related to the Central Asian countries in terms of nationality, language, culture, religious beliefs, customs and habits ${ }^{[2]}$. Therefore, the trade between Northwest China and Central Asia is very frequent. In addition, the one belt, one road strategy also put forward higher requirements for products, investment and import and export cooperation.

\section{CALCULATION OF ECONOMIC AND TRADE INFLUENCE DEGREE OF CENTRAL ASIAN COUNTRIES}

The "One belt, one road" plan has created favorable conditions for the sustainable development of Northwest
China $^{[3]}$. The northwest of China has been a key poverty alleviation area for a long time because of its vast territory, sparse population and rich resources. The "one belt, one road" proposal has greatly changed the economic structure of the northwest region. In western developed countries and European economic circle, it is an important hub ${ }^{[4]}$. One belt, one road, is to speed up trade activities and development, and make the northwest region an international channel connecting Central Asia, so that the city of Western Asia, Eastern Europe, Central Europe, Western Europe, Xi'an, Lanzhou, Urumqi and Kashi will play a better role in developing their economic strength and development space, and better promote and accelerate the sustainable economic development in Northwest China, so that the resources potential and area of the Northwest China will be improved ${ }^{[5]}$. Position advantage is further optimized and transformed into economic advantage. The spatial interaction ability and international trade are analyzed and predicted by gravity model ${ }^{[6]}$. Based on this, one belt, one road, and the FDI model for the economic and Trade Analysis of the northwest Asian border countries to the Central Asian countries are established. 


$$
F D I_{i}=\alpha+\beta_{1} G D P_{i}+\beta_{2} G D P_{i}+\beta_{3} \text { Relend }_{i}+\beta_{4} D_{i j}+\beta_{s} Y_{1}+\beta_{6} Y_{2}+\beta_{7} Y_{3}+\varepsilon_{i}
$$

For the impact of trade on FDI, there is a causal relationship between trade DIJ and FDI y, which is bidirectional, that is, only one factor has different impact on FDI. Based on the above algorithm, this paper focuses on the advantages and disadvantages of China's direct investment in the five Central Asian countries ${ }^{[7-8]}$. This advantage mainly comes from bilateral exogenous factors, so trade will not be included in the independent variable system ${ }^{[9-10]}$. Finally, three dummy variables representing $\mathrm{y}_{1}-\mathrm{y}_{3}$ are introduced as follows:

$$
Y_{1}=\left\{\begin{array}{c}
1,2000-2003 \\
0, \text { other }
\end{array}\right.
$$

$$
\begin{aligned}
& \text { LnFDI }=-17.32+0.37 \operatorname{Ln} G D P_{1}+0.30 \operatorname{LnGDP}_{t}-0.21 \text { Ln Relend }_{t}-1.78 \text { LnDij }_{t} \\
& \quad+0.02 Y_{1}+0.14 Y_{2}-0.09 \beta_{7} Y_{3}
\end{aligned}
$$

Among them:

$$
R^{2}=0.711 \quad P=0.0004
$$

China has one belt, one road strategy. China's economic and trade cooperation with five Central Asian countries is focused on economic and trade and foreign direct investment Therefore, taking international trade and international direct investment as research factors, the interest rate difference of long-term loans between the two sides (the scale reflects the benchmark income difference between the two sides) and the exchange rate (the exchange rate change of import and export trade) are combined. This paper discusses the import and export situation of China to Kazakhstan and the impact of FDI on Kazakhstan's economic growth. The analysis model is as follows:

$$
\begin{aligned}
& G D P_{t}=\alpha+\beta_{1} F D I_{i j}+\beta_{2} \text { Trade }_{i j} \\
& +\beta_{3} r_{i j t}+\beta_{4} e_{i j t}+\varepsilon_{i}
\end{aligned}
$$

Since the real meaning of the original data is annual growth rate, all five Central Asian countries have passed the stationary test. SPSS software is used for regression analysis to calculate the impact of China Kazakhstan economic and trade cooperation on bilateral economic growth

$$
\begin{aligned}
& G D P=5.01+0.11 F D I_{i j t}+0.317 \text { Trade }_{i j t} \\
& +0.191 r_{i j}+0.014 e_{i j}
\end{aligned}
$$

Among them:

$$
\begin{aligned}
& Y_{2}=\left\{\begin{array}{c}
1,2004-2007 \\
0, \text { other }
\end{array}\right. \\
& Y_{3}=\left\{\begin{array}{c}
1,2008-2009 \\
0, \text { other }
\end{array}\right.
\end{aligned}
$$

This paper selects the sample interval of trade data of Central Asia in recent years as a reference. The data are all annual data, and the data is from wind database. According to the requirements of regression analysis for data stationarity, the logarithm processing of all data is carried out to test the stationarity of sample data. After logarithm, the data passed the stationarity test, and the regression analysis was carried out by SPSS software. The specific algorithm is as follows. 
Central Asian countries are investigated. It is found that in recent years, the economy of Central Asian countries is in recession, and the economic growth rate of each country is declining. Only Uzbekistan is relatively stable, down $0.9 \%$ between 2014 and 2019. In the other four countries, the decline was even greater, at 5\%, $8.9 \%, 3.5 \%$ and $4.1 \%$. The results are as follows:

Tab. 1 Economic and trade changes of five Central Asian countries from 2014 to 2019 (unit:\%)

\begin{tabular}{ccccccc}
\hline & 201 & 2015 & 201 & 201 & 201 & 201 \\
& 4 & & 6 & 7 & 8 & 9 \\
\hline Kazakhstan & 6.0 & 6.0 & 4.3 & 1.0 & 1.0 & 1.0 \\
Kyrgyzstan & 7.0 & 10.9 & 4.0 & 3.5 & 3.8 & 2.0 \\
Tajikistan & 7.5 & 7.4 & 6.7 & 6.0 & 6.9 & 4.0 \\
Turkmenistan & 11.1 & 10.2 & 10.3 & 6.5 & 6.2 & 7.0 \\
Uzbekistan & 8.2 & 8.0 & 8.1 & 8.0 & 7.8 & 7.3 \\
\hline
\end{tabular}

"One belt, one road" has developed rapidly between China and five Central Asian countries. One belt, one road initiative has been developing rapidly in recent years, and the economic and trade relations between China and Central Asian countries have been developing rapidly. It can be seen that the economic and trade cooperation between the five countries in Central Asia has been increasing every year, and their long-term cooperation with China can be maintained. The economic and trade relations between Northwest China and Central Asian countries are developing rapidly. However, the value of goods imported from Xinjiang by the five Central Asian countries, especially Kyrgyzstan and Turkmenistan, is still very low. The bilateral trade volume is only 1 million US dollars, and it is still declining year by year. This shows that the industrial and agricultural production of Central Asian countries needs to be improved. Xinjiang's export volume to Kazakhstan is relatively large, with us $\$ 666.5$ million in 2014 and US \$878 million in 2016. Compared with Kyrgyzstan, Tajikistan and Turkey, China's exports still have a significant growth, with a large space for growth. Based on this, this paper investigates the import trade between Northwest China and five Central Asian countries.

Tab. 2 Import trade between Northwest China and five Central Asian countries in 2014-2018 (unit: million US dollars)

\begin{tabular}{ccccccccccc}
\hline & \multicolumn{2}{c}{ Kazakhstan } & \multicolumn{2}{c}{ Kyrgyzstan } & \multicolumn{2}{c}{ Tajikistan } & \multicolumn{2}{c}{ Turkmenistan } & \multicolumn{2}{c}{ Uzbekistan } \\
\cline { 2 - 10 } 2014 & Import & Export & Import & Export & Import & Export & Import & Export & Import & Export \\
2015 & 402.8 & 766.5 & 8.5 & 372.1 & 3.8 & 168.4 & 1.2 & 10.6 & 42.4 & 31.7 \\
2016 & 388.6 & 837.0 & 5.1 & 398.9 & 4.0 & 136.7 & 0.4 & 13.5 & 44.6 & 38.5 \\
2017 & 134.2 & 878.8 & 3.8 & 413.3 & 1.0 & 157.6 & 0.4 & 14.8 & 38.0 & 49.2 \\
2018 & 48.6 & 526.1 & 3.7 & 320.0 & 1.1 & 200.1 & 0.3 & 13.0 & 26.5 & 50.0 \\
\hline
\end{tabular}

In Central Asia, there are abundant energy resources such as oil and natural gas, nonferrous metals such as copper, zinc and tungsten, and rare metal resources such as gold. Most of the areas have not been developed yet, but due to the inland location, inconvenient transportation, slow foreign economic cooperation and lagging economic development. The development of economic and trade in Central Asia needs the financial and technical support of other countries. The development of economic and trade cooperation with

Central Asian countries needs the support of capital and technology. In addition, there are similarities between Northwest China and the five Central Asian countries in ideology, economic structure and so on. Historical and geographical factors have played an important role in strengthening the economic and trade exchanges between China and Central Asian countries. In order to better investigate, this paper takes 2018 as an example to analyze the resources and economic and trade development of the five Central Asian countries:

Tab. 3 Resource and trade summary of five Central Asian countries (2018)

\begin{tabular}{|c|c|c|c|c|c|}
\hline & Uzbekistan & Kazakhstan & Kyrgyzstan & Tajikistan & Turkmenistan \\
\hline Main resources & $\begin{array}{l}\text { Oil and gas } \\
\text { resources, } \\
\text { mineral } \\
\text { resources, } \\
\text { cotton }\end{array}$ & $\begin{array}{l}\text { Oil and gas } \\
\text { resources, iron, } \\
\text { copper, zinc and } \\
\text { other non- } \\
\text { ferrous metal } \\
\text { resources }\end{array}$ & $\begin{array}{l}\text { Gold, copper, } \\
\text { tungsten, tin } \\
\text { and other } \\
\text { elements, rich } \\
\text { water } \\
\text { resources }\end{array}$ & $\begin{array}{l}\text { Water } \\
\text { resources, } \\
\text { minerals } \\
\text { and other } \\
\text { resources }\end{array}$ & $\begin{array}{l}\text { Oil and natural gas } \\
\text { resources }\end{array}$ \\
\hline Major industries & $\begin{array}{l}\text { Textile, food } \\
\text { processing, } \\
\text { machinery and } \\
\text { equipment }\end{array}$ & $\begin{array}{l}\text { Mining of oil, } \\
\text { coal, iron ore, } \\
\text { gold, copper and } \\
\text { non-ferrous } \\
\text { metals }\end{array}$ & $\begin{array}{l}\text { Small scale } \\
\text { machinery, } \\
\text { textile, food } \\
\text { processing, } \\
\text { cement, shoes }\end{array}$ & $\begin{array}{l}\text { Aluminum, } \\
\text { cement, } \\
\text { vegetable } \\
\text { oil }\end{array}$ & $\begin{array}{l}\text { Natural gas, oil, } \\
\text { petroleum products, } \\
\text { textile }\end{array}$ \\
\hline $\begin{array}{l}\text { GDP (GDP, US } \\
\$ 100 \text { million) }\end{array}$ & 659.50 & 1950.5 & 71.58 & 80.45 & 443.62 \\
\hline GDP per capita & 2130 & 11028 & 1198 & 949 & 7534 \\
\hline
\end{tabular}




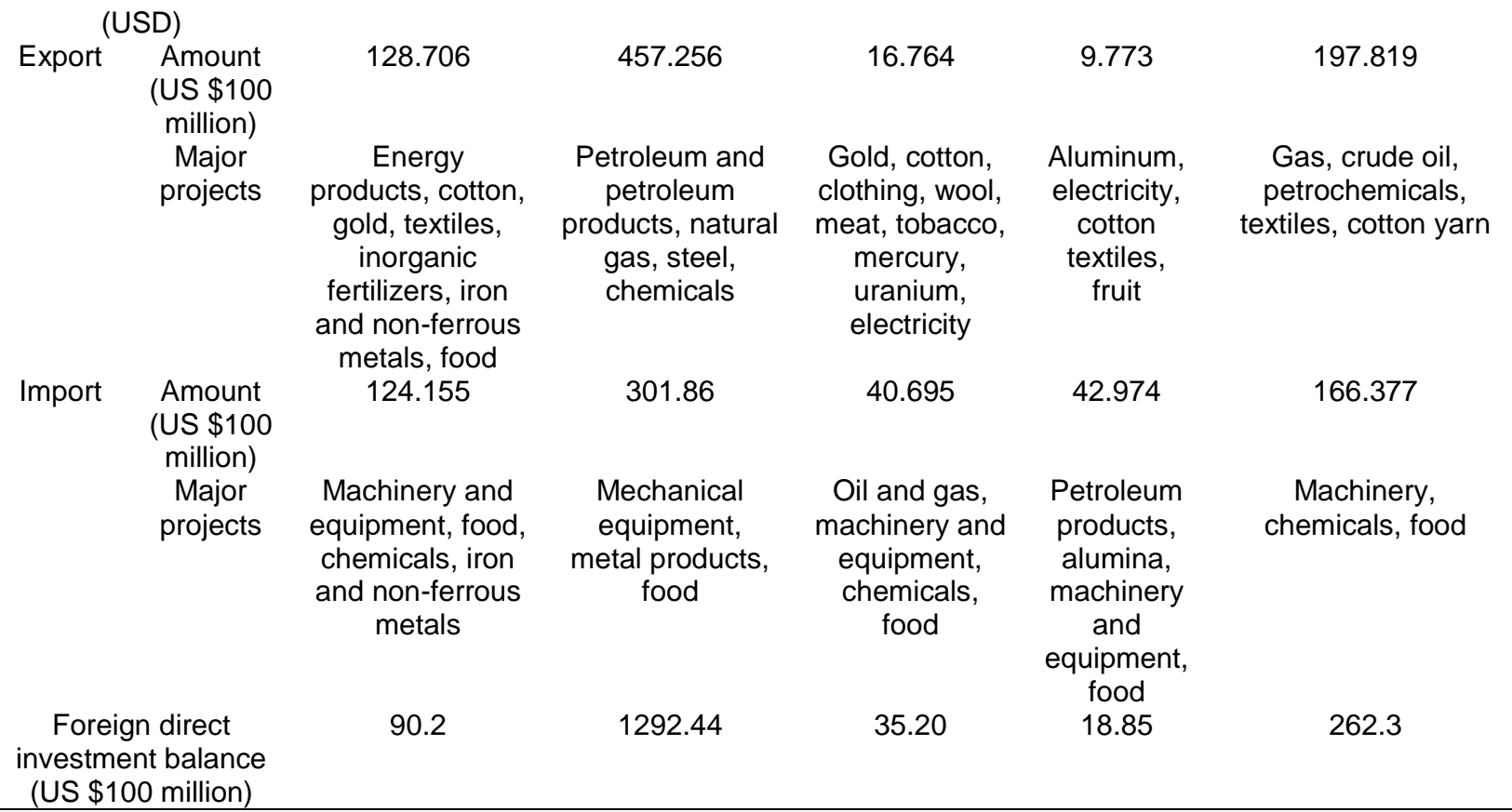

According to the table, the per capita GDP of the five Central Asian countries in 2018 is US \$1000, which is equivalent to the level of China. In terms of resources and industrial distribution, the five Central Asian countries are mainly engaged in the primary and secondary industries, and have strong labor-intensive characteristics. In the fields of home appliances, food, machinery, mechatronics, chemical industry and electronics, China's exports to Central Asia are more in line with the market demand and consumption structure of Central Asian countries. Among the Central Asian countries, China's industrial overlap and trade complementarity are relatively high.

Obviously, in terms of industrial demand, China Kazakhstan trade has more similarities. Based on the quantitative comparison of the similarity of China's commodity structure between Central Asia and the European Union, the United States, Russia and the global market, this paper analyzes the similarity index model based on the comparison of the economic and trade cooperation between the United States, Russia and other countries and Central Asia:
Tab. 4 Result Analysis of export similarity index model (ESI)

\begin{tabular}{ccccc}
\hline $\begin{array}{c}\text { Particular } \\
\text { year }\end{array}$ & $\begin{array}{c}\text { Global } \\
\text { market }\end{array}$ & $\begin{array}{c}\text { European } \\
\text { union }\end{array}$ & U.S.A & Russia \\
\hline 2013 & 27.95 & 11.66 & 17.54 & 42.21 \\
2014 & 27.02 & 10.62 & 17.00 & 47.83 \\
2015 & 22.39 & 8.37 & 18.56 & 48.88 \\
2016 & 28.50 & 7.24 & 17.68 & 52.39 \\
2017 & 22.01 & 7.09 & 17.71 & 51.69 \\
\hline
\end{tabular}

The results show that there are some differences in China's export trade competition. China Central Asia ESI index shows a downward trend in the developed regions of Europe and the United States, showing strong complementarity. The Russian market has geopolitical advantages, and the export trade competition is becoming increasingly fierce. According to the framework of competitive complementary trade management, using uncommertrade database, this paper establishes export similarity, trade integration, G-L, B-L and RCA index models, and evaluates and analyzes the development trend of trade cooperation management between China and Central Asia. The details are shown in Figure 1. 
International trade between China and Central Asia

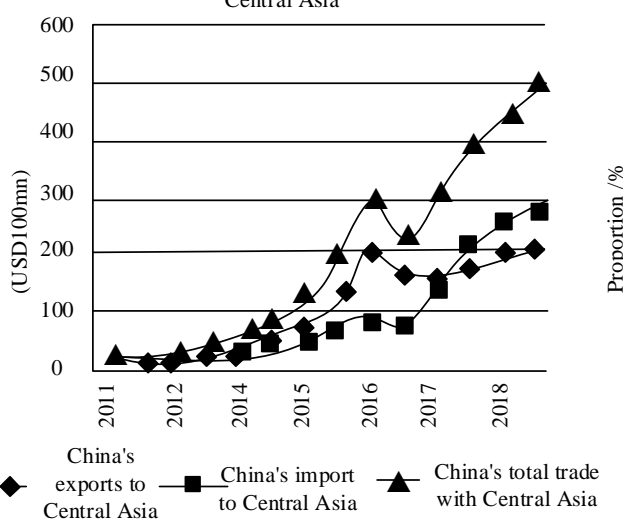

The change of China's proportion in the

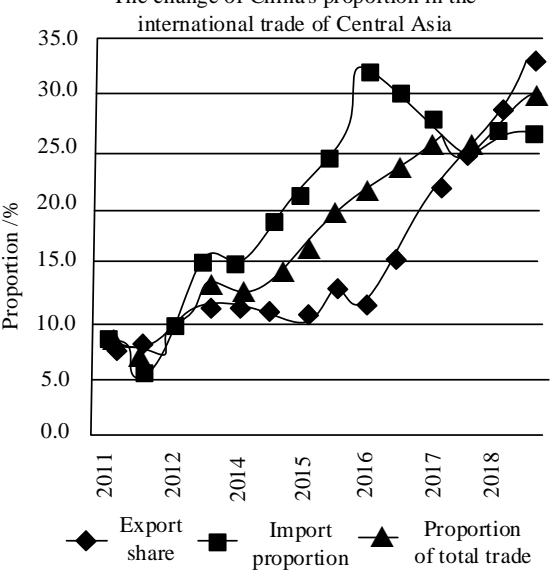

The change of the proportion of Central Asia in China's international trade

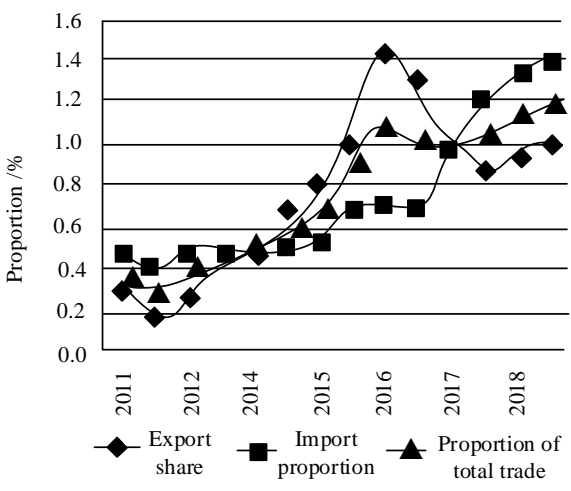

Trade proportion of main trade partners in Central Asia

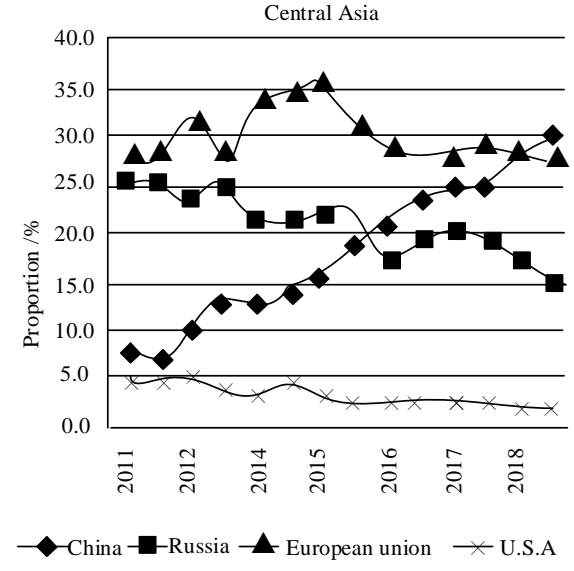

Fig. 1 Analysis of economic and trade changes and development trend in Central Asia

Driven by the empirical research results from 2011 to 2018, the contribution of China Kazakhstan import and export trade to Kazakhstan's economic growth has increased greatly. This period is a period of rapid development of China's foreign trade, especially the development of Sino Kazakhstan trade in mechanical and electrical products, which has played a great role in promoting Kazakhstan's economic growth. Northwest China is connected with Central Asian countries by mountains and rivers, and has a long tradition of the ancient Silk Road. Compared with the Central Asian countries, China's economic development level is close, the degree of industrial overlap is high, and China has strong cooperation potential and strong financial strength. The study shows that the implementation of the Central Asia Strategic Adjustment of openness, cooperation and win-win is conducive to enhancing China's position in the world economic order and political influence in the Asia Pacific region, and ensuring the long-term and healthy development of Central Asia's economy and trade. The "one belt, one road" initiative is a long-term blueprint for promoting financial cooperation between China and other countries, in order to better achieve economic development in the northwest and Central Asia. China should actively establish strategic cooperative relations with Central Asian countries. China's diplomatic cooperation with Central Asia must seek truth from facts, adhere to mutually beneficial cooperation, adhere to market orientation, and adhere to win-win results, otherwise it will bring diplomatic difficulties. We should give full consideration to the peace and sustainable development of Central Asian countries and take into account the interests of all parties. For Central Asia, public diplomacy and citizen diplomacy should be actively carried out, and the foreign policy of "walking on two legs" should be implemented to maintain its long-term influence. Increase cargo carrying capacity and ease port backlog. On this basis, we should actively promote the construction of E-port Information Platform of Northwest Central Asian countries, and realize the convenient customs clearance mode of "one report, one inspection and one release", which is conducive to the rapid customs clearance and transportation of goods.

\section{CONCLUSION}

The establishment of a free trade area is not a task that unilateral countries can accomplish, but requires cooperation among participating countries on the basis of common will. Whether the institutional arrangement of China Central Asia free trade area can be successfully formed and implemented depends on the common will. With China one belt, one road, the next step is to study 
the influence and development of the trans border ethnic groups on the economic and trade development of the Central Asian countries, so as to better promote the economic and trade construction and development in the region.

\section{REFERENCES}

[1] Yongli W, Haiyang Y, Xiaohai W, et al. Consideration of reliability and economy to Capacity Configuration of energy storage system: Case Study of a large scale wind power plant in the Northwest China[J]. Energy Procedia, 2018, 152(11):149-155.

[2] Muhammad S, Long X, Salman M, et al. Effect of urbanization and international trade on $\mathrm{CO} 2$ emissions across 65 Belt and Road Initiative Countries[J]. Energy, 2020, 196(10):117102.

[3] Sun H, Kofi E B, Song X, et al. Estimating Persistent and Transient Energy Efficiency in Belt and Road Countries: A Stochastic Frontier Analysis[J]. Energies, 2020, 13(15):3837.

[4] C J L F A B, D Y B D, E S L W A, et al. Determinants of carbon emissions in 'Belt and Road initiative' countries: A production technology perspective[J]. Applied Energy, 2019, 239(10):268-279.

[5] Xue H B, Zhang C M, Dang F N, et al. Limit equilibrium analysis method for loess slopes considering spatial-temporal evolution laws of parameters[J]. Yantu Gongcheng Xuebao/Chinese Journal of Geotechnical Engineering, 2018, 40(12):162-166.

[6] Muhammad S, Long X. China's seaborne oil import and shipping emissions: The prospect of belt and road initiative[J]. Marine Pollution Bulletin, 2020, 158(11):111422.

[7] Tan K H, Ji G, Chung L, et al. Riding the wave of belt and road initiative in servitization: Lessons from China[J]. International Journal of Production Economics, 2019, 211(5):15-21.

[8] Tan K H, Ji G, Chung L, et al. Riding the wave of belt and road initiative in servitization: Lessons from China[J]. International Journal of Production Economics, 2019, 211(5):15-21.

[9] Simonov E, Egidarev E. Intergovernmental cooperation on the Amur River basin management in the twenty-first century[J]. International journal of water resources development, 2018, 34(5):771791.

[10] Wiegmans B, Janic M. Analysis, modeling, and assessing performances of supply chains served by long-distance freight transport corridors $[\mathrm{J}]$. International journal of sustainable transportation, 2019, 13(1-5):278-293. 